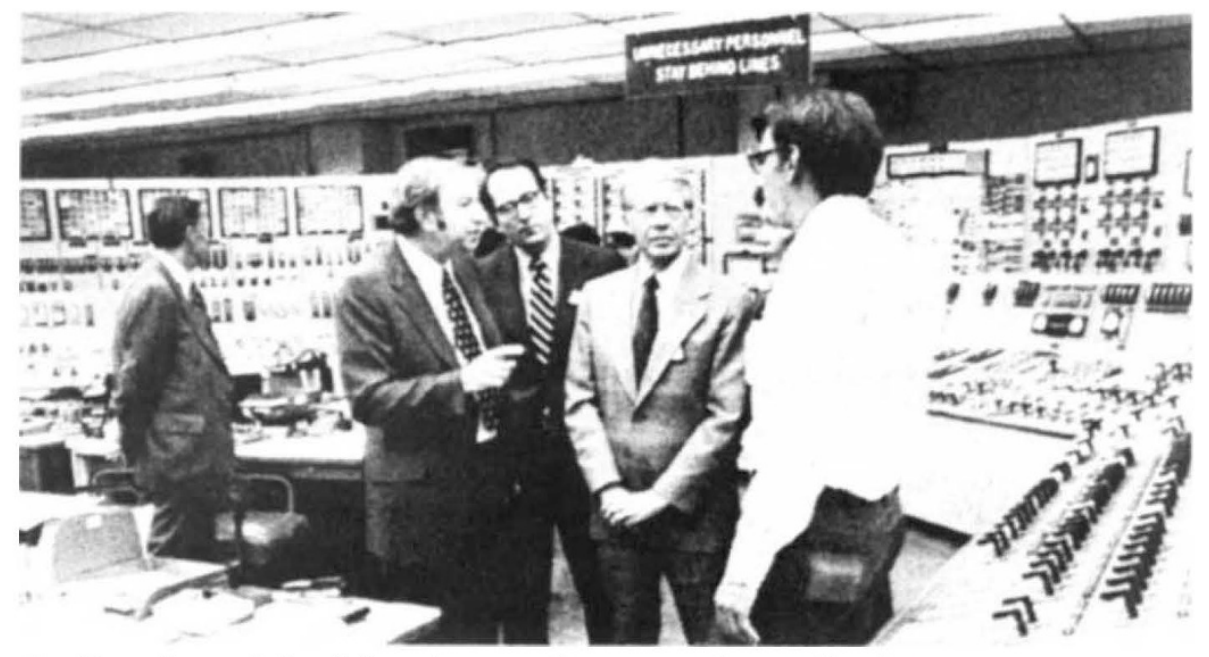

President Carter is briefed in the control room at Three Mile Island by Harold Denton of the NRC (left).

\section{Harrisburg: counting the cost}

Ar Harrisburg, the accident still poses enormous clean-up problems. The radiation level inside the reactor containment dome reached 30.000 rems per hour. and officials face the task of cleaning up 250,000 gallons of radioactive water from inside the reactor vessel itself. "We are looking at plans to bring the reactor to a cold shutdown without an increased leakage from the plant" said Harold Denton, Director of Reactor Regulation of the Nuclear Regulatory Commission (NRC). But Senator Morris Udall said it would lie months before any clean-up could begin. "if, indecd, a clean-up is possible".

In the meantime, there have been press reports blaming the Metropolitan Edison Company for violating Federal regulations for reactor operation. The International Herald Tribune cites detailed NRC reports that valves controlling the emergency water supply to the reactor's cooling system had becn closed for two weeks for routine maintenance. Mr Darrell Eisenhut, an engineer for the NRC., told a press conference that in addition the analyses showed that the main cooling system had been turned off at the wrong time and that four auxiliary pumps were disengaged in violation of Commission regulations. These faults combined to cause 60.000 gallons of radioactive water to flood the reactor chamber to a depth of eight feet. The zirconium in the reactor fucl cladding then combined with the water to release hydrogen gas which created a large 1.000 cubic feet bubble at the top of the vessel, causing the fuel rods to overheat and rupture relcasing fission products into the water.

In a letter to The Guardian in London, Sir Martin Ryle of the Cavendish Laboratory in Cambridge said that the deficiencies of the emergency corc cooling system of the Harrisburg family of pressurised water reactors (PWRs) had "been known publicly for five years and by the US Atomic Energy Commission for considerably longer". According to Ryle, the system consists of four separate methods of cooling and relies on correct working of monitored temperature, pressure and waterlevel and the correct sequencing of the various pumps and valves. "It is an excessively complicated system that has never been tested except for 'tests' by computer simulation", said Ryle. He added that the highly dangerous hydrogen bubble should have been predicted as a matter of "A-level textbook knowledge" or failing that as the result of an "afternoon's experiment",

In the financial world, the accident touched off heavy sales of nuclear power related stocks. The US stock market as a whole suffered a broad decline which was attributed to investers worrying over the implications of the accident for the US energy situation. However, stock in Columbia Pictures, owners of The China Syndrome, a film about a nuclear meltdown "somewhere in Pennsylvania', rose as its box office takings reached a new high. An anti-nuclear group in South Carolina reported that their phones had been busy 16 hours a day. "People call up and say I can't believe it. I saw the movie and then came home and saw the same thing on the 11 o'clock news."

Daniel Ford, executive director of the Union of Concerned Scientists. called on President Carter "to seek immediate removal" of Dr Joseph Hendrie as chairman of the NRC.. Ford was reported as saying that Hendrie had participated in a "far reaching coverup of critical nuclear safety difficulties"
Joe Schwartz
Joe Schwarz monitors world wide reactions

\section{'We all live in Pennsylvania..'}

IN THE UK, the Secretary of State for Energy, Tony Benn, said that before the accident he had faced continuous pressure to "go .4merican" and replace Britain's gas cooled reactors with American PWRs similar to the Harrisburg design. Pressure came from advisers, civil servants, and the nuclear industry itself, but he rejected the plan. Benn said the Harrisburg accident proved that "energy decisions must be kept under democratic control of Parliament". Prime Minister James Callaghan told Parliament: "We have been very wise in concentrating on a safer type of reactor." One of the three firms competing for the order of Britain's first PWR is Babcock and Wilcox; the others are the West German company Kraft Werke Union and a consortium which includes Rolls Royce and Northern Engineering.

France and West Germany, the two most committed nuclear nations in Europe. sent scientific teams to Harrisburg to inspect the accident. Iwo West German experts reported that the reactor was closer to a core meltdown than was publicly admitted.

The French Government announced its intention to proceed as usual with nuclear development, but the Opposition and the trade unions have called for a re-examination. Francois Mitterand. leader of the Socialist Party. accused the government of secrecy and high handedness in pushing through its power programme. The Socialist minority in parliament called for a halt to France's plan to build nine additional PWRs similar to the Harrishurg reactor in the next five years.

Prime Minister Raymond Barre told the European Press Club: "We must multiply our security measures but France cannot renounce nuclear energy". Minister of Industry Andre Giraud said: "An accident of this type has been taken into account in the dasign of French nuclear plants."

Le Monde reported numerous criticisms of the Government's stance. The Committec of Interregional Ecological Movements (CIME) demanded an immediate halt to the French nuclear programme because of the danger to urban centres. A Harrisburg-type accident. (IME said, would contaminate 300.000 people around the Fessenheim reactor (Mulhouse). 100.000 around Flamanville (Cherbourg) and 500.000 around Pellerin (Nantes).

'The most dramatic action in Firance 